4. Покровский А.В. Состояние сосудистой хирургии в России в 2013 году / А.В. Покровский, В.Н. Гонтаренко. - Москва, 2014. - 52 с.

5. Покровский А.В. Состояние сосудистой хирургии в России в 2014 году / А.В. Покровский, В.Н. Гонтаренко. - Москва, 2015. - 94 с.

6. Покровский А.В. Хирургия аневризм брюшной аорты / А.В. Покровский, В.С. Работников, Р.С. Ермолюк // Хирургия. - 1971. - № 12. - С. 31.

7. Большая медицинская энциклопедия. Т. 1 / Б.В. Петровский [и др.]. - Москва, 1974. - 576 с.

8. Большая медицинская энциклопедия. Т. 25 / Б.В. Петровский [и др.]. - Москва, 1985. - 544 с.

9. Национальные рекомендации по ведению пациентов с аневризмами брюшной аорты: Российский согласительный документ / Л.А. Бокерия, А.В. Покровский [и др.]. - Москва, 2013. - 72 с.

10. Российское общество ангиологов и сосудистых хирургов [электронный ресурс]. http://angiolsurgery.org (дата обращения: 12.05.2020).

11. Спиридонов А.А. Хирургическое лечение аневризм брюшной аорты / А.А.Спиридонов, Е.Г. Тутов, В.С. Аракелян. - Москва, 2000. - 206 с.

12. Казанчян П.О. Осложнения в хирургии аневризм брюшной аорты / П.О. Казанчян, В.А. Попов. Москва, 2002. -304 с.

13. Белов Ю.В. Аневризмы восходящей аорты с аортальной недостаточностью / Ю.В. Белов, Э.Р. Чарчян. - Москва, 2006. - 168 с.

14. Савельев В.С. Сосудистая хирургия: национальное руководство (краткое издание) / В.С. Савельев, А.И. Кириенко. - Москва, 2015. - 464 с.

15. World Association of Medical Editors (WAME) [electronic resource]. - http://www.wame.org (дата обращения: 12.05 .2020$)$.

\title{
Moskalets O.V. \\ SICAM-1 and SVCAM-1 in children with typical hemolytic uremic syndrome
} Moscow Regional Research Clinical Institute named after M.F.Vladimirskij (Russia, Moscow)

doi: 10.18411/scienceconf-09-2020-02

idsp: scienceconf-09-2020-02

Introduction .A typical hemolytic uremic syndrome is a disease from the group of thrombotic microangiopathies, the cause of which is an infection caused by Shiga toxin (Stx) -producing microorganisms, primarily enterohemorrhagic Escherichia coli. The disease most often affects children from 6 months to 5 years, although it is possible at any age, manifested by the development of a triad of symptoms - hemolytic anemia, thrombocytopenia, acute renal damage - after the prodromal period of acute intestinal infection, often hemocolitis. $[1,2,3]$

It was previously shown that high leukocytosis in the onset of tHUS is a predictor of the severity of the disease [4,5]. It can be assumed that other markers of systemic inflammation, such as tumor necrosis factor-alpha $(\mathrm{TNF} \alpha)$, soluble TNF- $\alpha$ receptor $(\mathrm{sTNF} \alpha \mathrm{R})$, interleukin 6 (IL-6) and soluble IL-6 receptor (sIL-6R), and also the antiinflammatory cytokine interleukin-10 (IL-10) may have prognostic value in tHUS in terms of the risk of cortical necrosis, neurological damage, and multiple organ failure.

The aim: To study the serum concentrations of TNF $\alpha$, sTNF $\alpha$ R, IL-6, sIL-6R, IL-10 in children in the acute phase of tHUS, as well as to assess their information content as markers of the severity and duration of the disease.

Material and methods. We examined 30 patients (17 boys, 13 girls) in the acute phase of tHUS and 21 children (12 boys, 9 girls) in the follow-up history. All children underwent ultrasound examination of the kidneys with dopplerography, a study of laboratory parameters characterizing the activity of TMA and hemolysis (hemoglobin, platelets, LDH), the severity of inflammation (leukocytes, C-reactive protein, C3 component of complement), the state of study the content of TNF $\alpha$ and sTNF $\alpha \mathrm{R}(60 \mathrm{kDa})$, IL-6 and sIL-6R, IL-10 for children in the acute phase of tHUS were taken on the first day from admission to the department (on days 2-4 from the onset of tHUS symptoms), children of the comparison group - with a routine follow-up examination. The above cytokines and their soluble receptors were determined by ELISA using test systems from eBioscience (Austria). 
Results. In children of the comparison group, the level of the studied cytokines did not go beyond the reference indicators, and the coagulation system (RFMC, D-dimer ), degree of renal damage (urea, creatinine). sTNFaR was not determined $(0 \mathrm{pg} / \mathrm{ml})$ in $47.6 \%$ of children in this group.

In the acute phase of tHUS in children, both normal and elevated values were noted. The levels of TNF $\alpha$ in all children in the acute phase of the disease were within normal limits (although higher than in the control group). sTNF $\alpha \mathrm{R}$ s levels were increased in $23.3 \%$ of children, IL-6 in $76.6 \%$, sIL-6R in $30.0 \%$, IL-10 in $36.7 \%$ (differences with the control group were significant for all cytokines, $\mathrm{p}<0.05$ ).

We did not find a reliable relationship between the level of the studied cytokines and their receptors with the clinical manifestations of the infectious process (fever and severity of hemocolitis). Reliable ( $\mathrm{p}<0.05)$ positive correlations of IL-6 and CRP level $(\mathrm{r}=0.76)$, negative correlation of IL-6 and C3 level (-0.68) were revealed. The level of IL-10 was significantly $(\mathrm{p}<0.05)$ correlated with the number of leukocytes at admission $(r=0.44)$. The duration of anuria as an indicator of the severity of the disease and the risk of long-term consequences was positively correlated with the number of leukocytes at admission $(r=0.64$, $\mathrm{p}<0.05)$, CRP level at admission $(\mathrm{r}=0.46, \mathrm{p}<0.05)$, and also the level of IL-10 $(\mathrm{r}=0.77, \mathrm{p}$ $<0.05)$.

Conclusion. Thus, in children in the acute phase of tHUS, in comparison with the catamnesis group, increased levels of a number of pro-inflammatory cytokines, as well as increased levels of anti-inflammatory cytokine IL-10, were found. At the same time, it can be assumed that with tHUS, the maximum active secretion of cytokines occurs at the height of the infectious process, at the time of prodromal Stxemia, i.e. in the prodromal period of tHUS. Subsequently, with the already developed symptoms of HUS (as in our patients), toxinemia decreases and the secretion of cytokines. is declining and, since the half-life of cytokines in vivo is short, their plasma level decreases. The detection of a high level of IL-6, IL-10 in patients in the early stages of tHUS, along with high leukocytosis and CRP level, can serve as a marker of a pronounced and prolonged systemic inflammatory response and a predictor of the severe course of the disease. IL-10 can be both a marker of severe systemic inflammation (since its secretion is triggered by pro-inflammatory cytokines), and also have its own adverse effect on the pathological process in tHUS by excessive immunosuppression.

The revealed correlations of the duration of anuria with leukocytosis, CRP level, a more pronounced decrease in C3 in the subgroup of children with severe tHUS confirm the adverse effect of severe systemic inflammation and complement activation on the severity of tHUS.

$$
* * *
$$

1. Emirova K.,Tolstova E.M., Kagan D.M et al. Hemolytic uremic syndrome associated with shiga-toxinproducing Esherichia coli. Nephrology. 2016. Vol.20, no 2. P.18-32 (in Russ.).

2. Talarico V., Aloe M., Monzani A. et al. Hemolytic uremic syndrome in children. Minerva Pediatr. 2016. Vol.68, no 6. P.441-445.

3. Karpman D. Management of Shiga toxin-associated Esherichia coli-induced haemolytic ureamic syndrome: randomized clinical trials are needed. Nephrol Dial Transplant.2012. Vol.27, no10. P.3669-3674.

4. Mody R.K., Gu W., Griffin P.M. et al. Postdiarrheal hemolytic uremic syndrome in Unated States children: clinical spectrum and predictors of in-hospital death. J. Pediatr. 2015. Vol.166, no 4. P.1022-1029.

5. Proulx F., Turgeon J.P., Litalien C.S. et al. Inflammatory mediators in Escherichia coli O157:H17 hemorrhagic colitis and hemolytic-uremic syndrome. Pediatr. Infect. Dis. J. 1998. Vol.7, no10. P.899-90 